\title{
Effect of Foliar Nutrition on Productivity and Profitability of Chickpea (Cicer arietinum L.) in Kymore Plateau of Madhya Pradesh
}

\author{
Ravi Kumar Tiwari* and H.S. Kushwaha \\ Department of Natural Resource Management, Faculty of Agriculture, Mahatma Gandhi \\ Chitrakoot Gramodaya Vishwavidyalaya, Chitrakoot, Satna, (M.P.) 485334, India \\ *Corresponding author
}

\section{A B S T R A C T}

Ke y w o r d s
Chickpea, Salicylic
acid, Boron, TNAU
Pulse Wonder,
Yield attributes,
Yield, Economics
Article Info
Accepted:
15 August 2020
Available Online:
10 September 2020

\section{Introduction}

Chickpea (Cicer arietinum L.) is highly nutritious and prime grain legume crop of India. Being a legume crop, it utilized atmospheric nitrogen through Rhizobial bacteria and improves soil health. India is the largest producer of chickpea and it accounts for about $33.99 \%$ of the total area and $40.92 \%$ of total pulse production in the country. However, it is cultivated over an area of $10.56 \mathrm{~m}$. ha, producing $11.23 \mathrm{~m}$. tonne and productivity of $1063 \mathrm{~kg} / \mathrm{ha}$ in India (Anonymous, 2018). Although, the highest contribution of area and production of this crop was from Madhya Pradesh (3.59 m. ha. and $4.60 \mathrm{~m}$. tonnes), but its productivity is low $(1280 \mathrm{~kg} / \mathrm{ha})$ than experimental field. The chickpea is constrained mainly by terminal drought because it is traditionally cultivated as a winter crop using either conserved soil moisture or limited irrigation facility. However, soil fertility especially macro and micronutrients, imbalanced use of fertilizer and occurrence of physiological disorders factors such as inefficient portioning of assimilates, poor pod setting, excessive flower abscission and lack of nutrient during critical stages of crop growth leads to nutrients stress, poor growth and yield. Thus additional 
nutrition through foliar feeding is played a vital role to fulfill the nutritional requirement in critical stages of chickpea. Foliar nutrition is a technique of feeding plant by liquid fertilizer directly to their leaves. The nutrient absorption takes place faster through their stomata but total absorption may be as great through the epidermis however, it is also absorbed nutrient through their bark. Foliar nutrition provides rapid nutrient supply, especially when soil nutrient availability or root activity is reduced. Hence, the present study was carried out to evaluate the effect of foliar feeding of nutrients on yield and economics of chickpea under irrigated condition of Kymore Plateau of Northern Madhya Pradesh.

\section{Materials and Methods}

The field experiment was conducted during rabi season of year 2016-17 at Agriculture Farm of Mahatma Gandhi Chitrakoot Gramodaya Vishwavidyalaya, Chitrakoot, Satna (M.P.). The soil of experimental plot was sandy loam in texture having soil $\mathrm{p}^{\mathrm{H}} 7.62$, available nitrogen $209.2 \mathrm{~kg} / \mathrm{ha}$, available phosphorus $16.8 \mathrm{~kg} / \mathrm{ha}$, available potassium $324.5 \mathrm{~kg} / \mathrm{ha}$ and available Boron $0.09 \mathrm{ppm}$.

The mean annual rainfall of Chitrakoot is 950 $\mathrm{mm}$ while, the crop received $56 \mathrm{~mm}$ rainfall during crop season i.e. October, 2016 to March, 2017. Eight treatment viz.- T $_{1}$ Control (water spray), $\mathrm{T}_{2}$; Urea @ 2\% spray at flower initiation, $\mathrm{T}_{3}$; TNAU pulse wonder @ 5kg/ha at flower initiation, $\mathrm{T}_{4}$; Salicylic acid @ 75 ppm at flower initiation and 7 days after first spray, $\mathrm{T}_{5}$; NPK 19:19:19 @ 2\% spray at flower initiation, $\mathrm{T}_{6}$; Urea @ 2\% + Salicylic acid 75 ppm at flower initiation, $\mathrm{T}_{7}$; Boron @ $0.25 \mathrm{ppm}$ spray at flower initiation, $\mathrm{T}_{8}$; Nitrobenzene @ 500 ppm spray at flower initiation, replicated thrice were tested in randomized block design The chickpea (cv. JG-16) was sown on Oct. 25, 2016 at a row spacing of $30 \mathrm{~cm}$ using $100 \mathrm{~kg}$ seeds/ha. The crop was fertilized $20 \mathrm{~kg} \mathrm{~N}, 50 \mathrm{~kg} \mathrm{P}_{2} \mathrm{O}_{5}$ and $20 \mathrm{~kg} \mathrm{~K} 2 \mathrm{O} / \mathrm{ha}$. Entire dose was applied as basal dressing in furrows. Crop was irrigated at pre-flowering (40 DAS) and pod development stage (65 DAS). One manual weeding was done at 30 days after sowing. The foliar nutrition was done as per treatments at flowering initiation (Jan. 04, 2017) and 7 days after first spray (Jan. 13, 2017) by knapsack sprayer with 600 litre water/ha. The crop was protected from insectpest through spray of Dimethoate @ 2ml/liter water twice at pod filling stage. Chickpea was harvested on March 14, 2017. The important yield attributes and grain and straw yield were recorded as per standard procedure. Economic were computed using the prevailing market prices for inputs and outputs (Grain Rs. 60/kg and straw 250/qt.). The experimental data was statistically analysed by Panse and Sukhatme (1985). The treatment differences were tested by using "F" test and critical differences at $5 \%$ probability.

\section{Results and Discussion}

\section{Branches and Yield Attributes}

The primary, secondary and tertiary branches per plant were influenced significantly by the foliar nutrition treatments. Foliar spray of salicylic acid $75 \mathrm{ppm}$ at flower initiation and 7 days after first spray gave the highest value of primary, secondary and tertiary branches per plant, which was at par the values obtained under TNAU pulse wonder $5 \mathrm{~kg} / \mathrm{ha}$ at flower initiation. This might be due to indeterminate growth habits of chickpea plant led to better branches per plant. Effect of salicylic acid on growth parameters was reported by Sujatha (2001) on green gram, Kumar et al., (2008) on black gram and Mohammadi et al., (2019) on wheat (Table 1 and 2). 
Table.1 Effect of foliar nutrition on branches per plant and yield attributes of chickpea

\begin{tabular}{|c|c|c|c|c|c|c|c|c|}
\hline \multirow[t]{2}{*}{ Treatment } & \multicolumn{3}{|c|}{ Branches/Plant } & \multicolumn{5}{|c|}{ Yield attributes } \\
\hline & Primary & Secondary & Tertiary & Pods/plant & Seeds/pod & Seeds/plant & $\begin{array}{c}\text { Seed } \\
\text { weight/plant(g) }\end{array}$ & $\begin{array}{l}\text { 1000- seed } \\
\text { weight }(\mathrm{g})\end{array}$ \\
\hline $\begin{array}{l}\text { Control } \\
\text { (water spray) }\end{array}$ & 4.9 & 10.4 & 4.3 & 34.80 & 2.00 & 55.00 & 8.47 & 160.80 \\
\hline $\begin{array}{l}\text { Urea spray } \\
2 \% \text { at FI }\end{array}$ & 6.7 & 10.9 & 6.1 & 41.33 & 2.02 & 57.60 & 9.35 & 160.43 \\
\hline $\begin{array}{l}\text { TNAU pulse } \\
\text { wonder } \\
5 \mathrm{~kg} / \mathrm{ha} \text { at FI }\end{array}$ & 6.8 & 13.7 & 7.6 & 40.87 & 2.12 & 57.80 & 9.36 & 160.47 \\
\hline $\begin{array}{l}\text { Salicylic acid } \\
75 \text { ppm at FI } \\
\text { and } 7 \text { days } \\
\text { after first } \\
\text { spray }\end{array}$ & 7.2 & 14.7 & 8.9 & 39.53 & 1.97 & 66.20 & 11.64 & 161.53 \\
\hline $\begin{array}{l}\text { NPK } \\
(19: 19: 19) \\
\text { spray 2\% at } \\
\text { FI }\end{array}$ & 5.6 & 12.4 & 5.1 & 39.20 & 1.95 & 54.00 & 9.51 & 160.80 \\
\hline $\begin{array}{l}\text { Urea } 2 \%+ \\
\text { Salicylic acid } \\
75 \text { ppm at FI }\end{array}$ & 5.9 & 12.5 & 4.7 & 40.27 & 2.00 & 55.80 & 9.32 & 160.63 \\
\hline $\begin{array}{l}\text { Boron } 0.25 \\
\text { ppm at FI }\end{array}$ & 6.1 & 11.5 & 5.3 & 43.60 & 2.08 & 58.67 & 9.77 & 161.87 \\
\hline $\begin{array}{l}\text { Nitrobenzene } \\
500 \text { ppm at FI }\end{array}$ & 6.1 & 12.6 & 5.3 & 39.07 & 2.00 & 55.73 & 9.63 & 161.83 \\
\hline $\mathrm{SEm} \pm$ & 0.38 & 0.80 & 0.84 & 1.48 & 0.05 & 2.23 & 0.41 & 0.63 \\
\hline $\begin{array}{c}\mathrm{CD} \\
(\mathrm{P}=0.05)\end{array}$ & 1.15 & 2.42 & 2.55 & 4.50 & NS & 6.78 & 1.24 & NS \\
\hline
\end{tabular}

$\mathrm{FI}=$ Flower initiation 
Table.2 Effect of foliar nutrition on yield, harvest index and economic of chickpea

\begin{tabular}{|c|c|c|c|c|c|c|c|}
\hline \multirow[t]{2}{*}{ Treatments } & \multicolumn{2}{|c|}{ Yield (kg/ha) } & \multirow{2}{*}{$\begin{array}{l}\text { Harvest } \\
\text { index } \\
(\%)\end{array}$} & \multicolumn{4}{|c|}{ Economics } \\
\hline & Seed & Straw & & $\begin{array}{c}\text { Cost of } \\
\text { cultivation } \\
\text { (₹/ha) }\end{array}$ & $\begin{array}{l}\text { Gross } \\
\text { monetary } \\
\text { returns } \\
(₹ / h a)\end{array}$ & $\begin{array}{l}\text { Net } \\
\text { returns } \\
\text { (₹/ha) }\end{array}$ & $\begin{array}{l}\text { B: } \mathrm{C} \\
\text { ratio }\end{array}$ \\
\hline Control (water spray) & 1968 & 2766 & 41.90 & 29,054 & 124,974 & 95,920 & 4.30 \\
\hline Urea spray $2 \%$ at FI & 2126 & 2781 & 43.45 & 29,137 & 134,511 & 105,374 & 4.62 \\
\hline $\begin{array}{l}\text { TNAU pulse wonder } \\
5 \mathrm{~kg} / \mathrm{ha} \text { at FI }\end{array}$ & 2361 & 3274 & 42.33 & 29,824 & 149,845 & 120,021 & 5.02 \\
\hline $\begin{array}{l}\text { Salicylic acid } 75 \text { ppm } \\
\text { at FI and } 7 \text { days after } \\
\text { first spray }\end{array}$ & 2514 & 3318 & 43.34 & 30,304 & 159,139 & 128,835 & 5.25 \\
\hline $\begin{array}{l}\text { NPK }(19: 19: 19) \text { spray } \\
2 \% \text { at FI }\end{array}$ & 2009 & 2770 & 42.35 & 31,154 & 127,477 & 96,323 & 4.09 \\
\hline $\begin{array}{l}\text { Urea } 2 \%+\text { Salicylic } \\
\text { acid } 75 \text { ppm at FI }\end{array}$ & 2286 & 2855 & 44.78 & 30,387 & 144,317 & 113,930 & 4.75 \\
\hline Boron $0.25 \mathrm{ppm}$ at FI & 2331 & 3226 & 41.89 & 29,055 & 147,944 & 118,889 & 5.09 \\
\hline $\begin{array}{l}\text { Nitrobenzene } 500 \\
\text { ppm at FI }\end{array}$ & 2099 & 2842 & 42.86 & 29,114 & 133,045 & 103,931 & 4.57 \\
\hline $\mathrm{SEm} \pm$ & 108.4 & 148.0 & 1.58 & - & 6593 & 6593 & 0.22 \\
\hline $\mathrm{CD}(\mathrm{P}=0.05)$ & 328.8 & 448.9 & NS & - & 20,000 & 20,000 & 0.67 \\
\hline
\end{tabular}

FI: Flower initiation

Muhal et al., (2014) and Mujalde (2016) also reported the beneficial effects of salicylic acid on the growth.

Yield attributes like number of pods per plant, seeds per plant and seed weight per plant were influenced significantly by the foliar nutrition treatments, however seeds per pod and 1000 seed weight were not affected significantly by different foliar nutrition treatments. Numbers of seeds per plant and seed weight per plant were registered significantly higher under salicylic acid 75 ppm at flower initiation and 7 days after first spray, while number of pods per plant was found significantly superior with the spray of Boron $0.25 \mathrm{ppm}$ at flower initiation. The growth and development of the plants depends on the initiation of tissues and organ primordial and on the differential and expansion of cells. Several metabolic activities are associated with this phenomenon, which involves the uptake of nutrients, synthesis of metabolites and the transport of substances within the plant body. Better yield attributes might be due to greater accumulation of carbohydrates and their translocation from source to the sink. Kumar et al., (2013) confirmed the result due to application of TNAU Pulse Wonder. Das et al., (2013) and Padbhushan and Kumar (2014) advocated the beneficial effects of boron on yield attributes. The findings of Marimuthu and Surendran (2015) and Sachin et al., (2019) also confirmed the incremental effects of TNAU pulse wonder on the yield attributes of black gram.

\section{Grain and Straw yield}

Application of foliar nutrition, salicylic acid $75 \mathrm{ppm}$ at flower initiation and 7 days after 
first spray being statistically at par with TNAU pulse wonder $5 \mathrm{~kg} / \mathrm{ha}$ at flower initiation, gave significantly highest seed yield of $2514 \mathrm{~kg} / \mathrm{ha}$ and $2361 \mathrm{~kg} / \mathrm{ha}$, respectively followed by Boron spray 0.25 ppm at flower initiation. Almost similar trend of straw yield (3318 kg and $3274 \mathrm{~kg}$ ) was recorded.

This increases in seed and straw yield was obtained due to accordance with the similar increases in the yield attributing characters. Such effects of salicylic acid on the yield of chickpea have been reported by Sujatha (2001) and Amutha et al., (2012). Marimuthu and Surendran (2015), Mujalde (2016) and Sachin et al., (2019) advocated the positive effects of TNAU pulse wonder @ $5 \mathrm{~kg} / \mathrm{ha}$ as foliar spray for the higher productivity of pulse crops. Beneficial effect of Boron was in accordance with the findings of Mujalde (2016). The harvest index was not influenced with treatment. It was might be due to equal grain ratio into total biomass yield.

\section{Economic}

Gross monetary returns (₹ 159139/ha) and net income (₹ 128835/ha) were achieved significantly maximum under foliar spray of salicylic acid $75 \mathrm{ppm}$ at flower initiation and 7 days after first spray closely followed by ₹ 149845/ha gross monetary returns and ₹ $120021 /$ ha net returns with the spraying of TNAU Pulse Wonder $5 \mathrm{~kg} / \mathrm{ha}$ at flower initiation. This could be ascribed due to higher market price of grain. It was almost similar pattern as grain and straw yield of chickpea. It was supported by the findings of Kumar et al., (2013). The benefit: cost ratio was in similar trend of gross and net returns. The cultivation cost was variable due to variable cost of treatments. It was confirmed by Marimuthu and Surendran (2015) and Mujalde (2016).
Thus, it may be concluded that, the foliar nutrition treatment with twice spray of salicylic acid $75 \mathrm{ppm}$ at flower initiation and 7 days after first spray was found the best practices for getting higher production and net returns in chickpea under irrigated condition of Kymore Plateau.

\section{References}

Amutha, R., Nithila, S. and Shiv Kumar (2012). Management of Source limitation by foliar spray of nutrients and growth regulators in Black gram. International Journal Plant Science 7(1): 65-68

Anonymous (2018). Agriculture Statistics at a Glance. Ministry of Agriculture and Farmers Welfare. Government of India.

Kumar Jeya P., Velu, G., Rajendran, C., Amutha, R., Savery, M. A. J. R. and Chidambaram, S. (2008). Varied responses of black gram (Vigna mungo L.) to certain foliar applied chemicals and plant growth regulators. Legume Research 31: 105-109

Kumar, C. Vinoth, Vaiyapuri K., Amnullah, M. Mohamed and Gopala Swamy, G. (2013). Influence of foliar spray of Nutrients on yield and economics of soybean [Glycine max. (L.) Merril]. Journal of Biological Sciences 13 (6): 563-565

Marimuthu S. and Surendran U. (2015). Effect of nutrients and plant growth regulators on growth and yield of black gram in sandy loam soils of Cauvery new delta zone. Indian Cogent Food \& Agriculture 1(1):1-9.

Mohammadi, M., Chaichi, Mohammad Reza and Safikhani, Sara (2019). Salicylic acid application alleviates the salt stress effects in wheat. International Journal of Development Research 9(1): 2497624981.

Muhal, Sarita, Solanki, N.S., Singh P. and 
Shukla, K.B. (2014). Effect of salicylic acid on productivety and nutritent uptake of Brassica species under different planting durations. African Journal of Agriculture Research 9(13):1101-1106.

Mujalde, Deepika (2016). Foliar nutrition on green gram [Vigna radiata (L.) Wilczek] productivity. M. Sc. (Ag) thesis M. G. G. V. V., Chitrakoot, Satna (M.P.) India.

Padbhushan, Rajeev and Kumar, Dinesh (2014). Influence of soil and foliar applied boron on green gram in calcareous soils. International Journal of Agriculture, Environment and Biotechnology 2(1): 129-136.

Panse, V.G. and Sukhatme, P.V. (1985). Randomized Block and Latin square designs. Statistical Methods for Agricultural Workers, ICAR, New
Delhi. pp. 152-165.

Sachin, A.S., Sivakumar, T., Krishna Surendar, K. and Senthivelu, M. (2019). Influence of plant growth regulators and nutrients on biometric growth and yield attributes in blackgram (Vigna mungo L). Journal of Agriculture and Ecology 7: 55-63.

Das, Shrila, Pareek, Navneet, Raverkar, K.P., Chandra, R. and Kaustav, Aditya (2013). Effectiveness of micronutrient application and Rhizobium inoculation on growth and chickpea. International Journal of Agriculture, Environment and Biotechnology 5: 545-552.

Sujatha, K. B. (2001). Effect of foliar spray of chemicals and bio regulators on growth and yield of green gram (Vigna radiata). M. Sc. (Ag) thesis Tamil Nadu Agriculture University, Coimbatore.

\section{How to cite this article:}

Ravi Kumar Tiwari and Kushwaha, H. S. 2020. Effect of Foliar Nutrition on Productivity and Profitability of Chickpea (Cicer arietinum L.) in Kymore Plateau of Madhya Pradesh. Int.J.Curr.Microbiol.App.Sci. 9(09): 1333-1338. doi: https://doi.org/10.20546/ijcmas.2020.909.169 